\title{
Present distribution, population status, and conservation of Western Hoolock Gibbons Hoolock hoolock (Primates: Hylobatidae) in Namdapha National Park, India
}

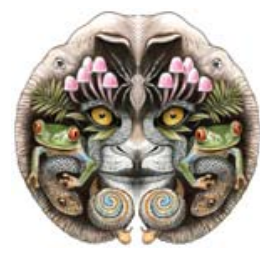

\author{
Awadhesh Kumar ${ }^{1}$, P.P. Mary ${ }^{2}$ \& Pushkal Bagchie ${ }^{2}$ \\ ${ }^{1}$ Lecturer, ${ }^{2}$ Department of Forestry, Northeastern Regional Institute of Science \& Technology (NERIST), Deemed University, Nirjuli, \\ Itanagar, Arunachal Pradesh 791109, India \\ Email: ${ }^{1}$ reshi123in@yahoo.co.in, tpileatus@gmail.com
}

\begin{abstract}
A survey on the present distribution, population status and conservation of Western Hoolock Gibbon (Hoolock hoolock) was conducted from September 2006 to April 2007 in Namdapha National Park, Arunachal Pradesh, northeastern India. The data were recorded from 12 localities in the Park: Gibbon land, Baghnallah, Deban, 15th Mile, 16th Mile, Hawaghar, 19th Mile, Haldibari, Hornbill camp, Baranallah, Firmbase camp, and Embyong. A total of 50 individuals in 20 groups were recorded during the census by using direct and indirect methods. Out of 20 groups, nine groups were observed through direct visual observation. The remaining 11 groups were estimated by using indirect observation methods such as songs, calls, and branch shaking. The composition of the population was 19 adult males (38\%), 19 adult females (38\%), and 12 immatures (24\%). The group size was estimated as 2.5 individuals per group. Anthropogenic disturbances observed in the gibbon habitat were habitat loss, hunting and poaching, canopy gaps, livelihood issues for local people, and livestock grazing.
\end{abstract}

Keywords: Canopy gaps, conservation, distribution, Hoolock Gibbon, Namdapha National Park, population status.

Date of publication 26 April 2009 ISSN $0974-7907$ (online) | 0974-7893 (print)

Editor: Mewa Singh

Manuscript details:

Ms \# 01955

Received 29 February 2008

Final revised received 09 September 2008

Finally accepted 11 November 2008

Citation: Kumar, A., P.P. Mary \& P. Bagchie (2009). Present distribution, population status, and conservation of Western Hoolock Gibbons Hoolock hoolock (Primates: Hylobatidae) in Namdapha National Park, India. Journal of Threatened Taxa 1(4): 203-210.

Copyright: (c) Awadhesh Kumar, P.P. Mary \& Pushkal Bagchie 2009. Creative Commons Attribution 3.0 Unported License. JoTT allows unrestricted use of this article in any medium for non-profit purposes, reproduction and distribution by providing adequate credit to the authors and the source of publication.

\section{Author Details: See end of article}

Author contributions: PUSHKAL BAGCHIE collected the data in the field on population status of Hoolock Gibbon in Namadapha. AWADHESH KUMAR and P.P. MARY assisted in the analysis and compilation of field data, and in writing of manuscript.

Acknowledgements: See end of this article

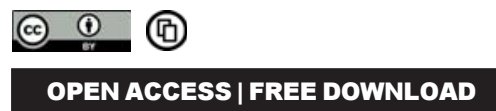

\section{INTRODUCTION}

India has 32 taxa of primates in the wild (Molur et al. 2003). Of these, the Western Hoolock Gibbon Hoolock hoolock and Eastern Hoolock Gibbon Hoolock leuconedys are two species of lesser apes found in India (Das et al. 2006). The Hoolock Gibbon was formerly associated with genera Hylobates (Prouty et al. 1983a, 1983b) and Bunopithecus (BrandonJones et al. 2004; Groves 2005). Today it is classified in the genus Hoolock (Mootnick \& Groves 2005) with two species: Western Hoolock Gibbon Hoolock hoolock from northeastern India south of the Brahmaputra River (Mukherjee 1982; Alfred \& Sati 1986; Choudhury 1987), Bangladesh (Anderson 1878; Siddiqi 1986; Das et al. 2003a) and western Myanmar (Tickell 1864), and Eastern Hoolock Gibbon H. leuconedys from Lohit District of Arunachal Pradesh, India (Das et al. 2006), Myanmar and China (Groves 1971; Anderson 1978; Lan 1994). The Debang-Bramhaputra river system in the west (Tilson 1979) and Chindwin in the east act as physical barriers for the distribution of species (Parsons 1941; Groves 1967, 1972; Choudhury 1987). In India and Bangladesh, the Hoolock range is strongly associated with the occurrence of contiguous canopy, broad-leaved, tropical wet evergreen and semievergreen forests.

The population of $H$. hoolock in the wild has declined by more than $90 \%$ over the past three decades due to numerous anthropogenic threats (Walker et al. 2007). The debilitating threats include habitat destruction and fragmentation as a result of agricultural expansion, shifting cultivation, establishment of tea gardens, coffee estates, logging, developmental projects, and hunting and poaching for food, traditional medicine, body parts, pet collection, and illegal trade (Choudhury 1990, 1991, 1996a; Mukherjee et al. 1992; Srivastava 1999; Ahmed 2001; Malone et al. 2002; Solanki \& Chutia 2004; Das et al. 2006; Walker et al. 2007). These threats occur in Arunachal Pradesh as well as in other areas of its distribution (Srivastava et al. 2001a, 2001b) and may have a direct impact on the population growth and distribution pattern of Hoolock hoolock due to its dependency on forest canopy for habitat, its being frugivorous, a brachiator and its territorial behaviors. Owing to its being frugivorous, the species plays a vital role as a seed disperser and pollinator (Howe 1986; Terborgh 1990) in lowland tropical rain forest ecosystems. Because of the evidence of widespread and rapid population decline, H. hoolock is listed by the IUCN Red List of Threatened Species as Endangered (Brockelman et al. 2008). In Bangladesh it is categorised as Critically Endangered, while in India it is Endangered as per the IUCN Regional Red List (Molur et al. 2003). In India the species is listed in Schedule I of the Indian Wildlife (Protection) Act 1972, and also in Appendix I of CITES. Against such a backdrop and the importance of the species for conserving the forest ecosystem, we realized that there still are various gaps with respect to the conservation of H. hoolock in Arunachal Pradesh. These gaps in our knowledge require immediate attention to save this species from its current threat status and were the impetus of this study. 
Most of the studies on the Western Hoolock Gibbon's population and distribution status have been conducted in northeastern India including Assam (Choudhury 1990; 1996a, 1996b, 2000, 2001; Das et al. 2003a, 2003b, 2004, 2005, 2006a, 2006b), Meghalaya (Tilson 1979; Alfred \& Sati 1986, 1990; Chaudhury 1998, 2006; Gupta \& Sharma 2005a), Mizoram (Misra et al, 1994; Gupta \& Sharma 2005b; Chaudhury 2006), Tripura (Das et al. 2005; Gupta \& Dasgupta 2005), Nagaland (McCann 1933; Chaudhury 2006) and Manipur (Chaudhury 2006). A few studies were conducted between 1988 and 2003, and these were concerned only with general distribution patterns (Mukherjee et al. 1988, 199192; Borang \& Thapliyal 1993; Singh 2001; Chaudhury 2003). The sole exception is Chetry et al. (2003) who conducted a quantitative study on the population status of gibbons in Namdapha National Park (NNP), Arunachal Pradesh. Gibbon habitat has been severely affected by anthropogenic causes during the intervening period and no quantitative distribution and population status has been conducted. Therefore, in this article we present quantitative information on the present distribution, population status, and conservation of $H$. hoolock in NNP and compare our results with those of previous studies.

\section{Materials and Methods}

\section{Study Area:}

Namdapha National Park (2723'30”-27039'40'N \& $96^{\circ} 15^{\prime} 2^{\prime \prime}-96^{\circ} 58^{\prime} 33^{\prime \prime} \mathrm{E}$ ) is located in the easternmost part of Arunachal Pradesh in Changlang District. It has an area of $1985 \mathrm{~km}^{2}$ with a core area of $1808 \mathrm{~km}^{2}$. The park is bordered on the north by the Kamlang Wildlife Sanctuary and to the west by the Noa-dihing River. To the south and southeast lie high mountain ranges and the international border with Myanmar. It is contiguous with reserve forests and sanctuaries to the south and west, which act as buffer zones. Due to altitudinal variation $(200-4571 \mathrm{~m})$, the climatic conditions are heterogeneous across the park. The temperature varies from $35^{\circ} \mathrm{C}$ to $0^{\circ} \mathrm{C}$ at lower altitudes and ranges to below freezing at higher elevations. The annual precipitation ranges from a minimum of $1400 \mathrm{~mm}$ to a maximum of $2500 \mathrm{~mm}, 75 \%$ of which falls between April and October. Relative humidity remains high except during the winter months, and annually it varies from a minimum of $47 \%$ to a maximum of $93 \%$.

There are three major forest types -- tropical, temperate and alpine forest (Champion \& Seth 1968) in NNP. The highly diverse flora of NNP includes 73 species of lichens, 59 species of Hepaticae (Bryophytes), 112 species of Pteridophytes, five species of gymnosperms, and 870 species of angiosperms (Hajra 1996). A total of 200 plant species belonging to 73 families was recorded by Nath et al. (2005) in three stands of NNP. The predominant vegetation at lower elevations is the tropical wet evergreen forest dominated by Dipterocarpus macrocarpus, Shorea assamica, Mesua ferrea, Altingia excelsa, Elaecocarpus aristantus, and Terminalia myriocarpa and reaching a height of $50 \mathrm{~m}$.

Faunal diversity is also high in Namdapha. Ninety-six species of mammals, 233 species of birds, 76 species of fish and 25 species of amphibians have been reported here (Ghosh 1987). Besides these, invertebrates included 188 species of beetles, 102 butterflies, 35 moths, 24 Hemiptera, and 115 Mantodea (Ghosh 1987). Similar to other protected areas in the region, NNP has 27 villages, made up of 1420 households and a tribal population of 9618 people, in and around the park (Arunachalam et al. 2004). The Chakma (3951 individuals), a Tibeto-Burman tribe, dominate the local population followed by Nepali, Lisu, Lama, and Mishmi (Table 1).

\section{Methods}

The present distribution and population status of H. hoolock was carried out at 12 specific localities in NNP from September 2006 to May 2007 based on information gathered from the literature, forest department, and local inhabitants. The population was estimated by a modified line transect method (Burnham et al. 1980; NRC 1981) and direct count method in different forest types. The line transects were laid in a stratified random manner to cover all selected areas in the park. Three observers walked slowly covering a distance of between 10 and $15 \mathrm{~km}$ per day between $0600 \mathrm{hr}$ and $1730 \mathrm{hr}$ or until sunset. While sighting the presence of gibbon by direct or indirect methods, such as calls, branch shaking, and sounds associated with locomotion and feeding, observers recorded the exact count of each group size, composition, and sex in addition to vegetation type and evidence of anthropogenic disturbances in its habitat. Age and sex compositions of $H$. hoolock were classified into two major age categories, adult and immature; these were further subdivided into four subcategories, adult, sub-adult, juvenile and infant, based on morphological differences as described by Gupta et al. (2005).

\section{RESULTS}

\section{Population distribution}

The population survey was mostly concentrated in the buffer zone areas of NNP except for a few areas of the core zone. The core zone of the park is completely inaccessible due to dense vegetation and hilly terrain. Nine populations of $H$. hoolock were found throughout the entire tropical evergreen forest of NNP and three populations were recorded from subtropical moist-deciduous and bamboo thick forest. They occur in all the different tree associations and were observed at altitudes from 150 to $800 \mathrm{~m}$. The majority of the groups were sighted at an elevation of $500 \mathrm{~m}$. They were found to be sympatric with the Capped Langur (Trachypithecus pileatus).

Ninety-five $\mathrm{km}$ of transects were laid and surveyed for the presence of $H$. hoolock in 12 different localities of NNP (Table 2). In these 12 localities we recorded a total of 20 groups. Eleven groups $(55 \%)$ were recorded by indirect observations, with nine groups $(45 \%)$ observed directly. The majority of the NNP gibbon population ( 17 groups) was recorded in tropical evergreen forest. Of the 20 groups, 12 groups (60\%) were recorded from four localities namely Gibbon land, Hawaghar, Hornbill camp, and Firmbase camp.

\section{Group composition and size}

A total of 50 individuals were recorded in the 20 groups during population estimation. The group size and composition of the population surveyed in different localities are presented in Table 2. The smallest group contained a single sub-adult solitary male. Of the 50 individuals, $19(38 \%)$ were adults males, $19(38 \%)$ were adults females, $2(4 \%)$ were sub-adults, $2(4 \%)$ were juveniles, and $8(16 \%)$ were infants (Fig. 1). The sub-adults, juveniles, and infants formed the immature class comprising $24 \%$ of the total population. The average group size was estimated 
Table 1. Human profile of dependent villages in and around Namdapha National Park (Arunachalam et al. 2004)

\begin{tabular}{|c|c|c|c|c|c|c|}
\hline $\begin{array}{l}\text { Periphery of Park } \\
\text { and total villages }\end{array}$ & Name of community & $\begin{array}{l}\text { No. of village of } \\
\text { particular community }\end{array}$ & Migrated from & $\begin{array}{l}\text { Total no.of } \\
\text { households }\end{array}$ & $\begin{array}{l}\text { Total human } \\
\text { population }\end{array}$ & $\begin{array}{l}\text { Population/ } \\
\text { household }\end{array}$ \\
\hline $\begin{array}{l}\text { Northwestern } \\
\text { periphery (12) }\end{array}$ & $\begin{array}{l}\text { Lama } \\
\text { Chakma } \\
\text { Mishmi } \\
\text { Singpho }\end{array}$ & $\begin{array}{l}01 \\
09 \\
01 \\
01\end{array}$ & $\begin{array}{l}\text { Bhutan } \\
\text { Bangladesh } \\
\text { Lohit district } \\
\text { Patkai range }\end{array}$ & $\begin{array}{l}23 \\
658 \\
11 \\
12\end{array}$ & $\begin{array}{l}122 \\
3951 \\
50 \\
68\end{array}$ & $\begin{array}{l}5.30 \\
6.00 \\
4.54 \\
5.67\end{array}$ \\
\hline $\begin{array}{l}\text { Southeastern } \\
\text { periphery (13) }\end{array}$ & $\begin{array}{l}\text { Lisu } \\
\text { Nepali }\end{array}$ & $\begin{array}{l}04 \\
09\end{array}$ & $\begin{array}{l}\text { Myanmar } \\
\text { Assam rifle ex-service man }\end{array}$ & $\begin{array}{l}385 \\
288\end{array}$ & $\begin{array}{l}2742 \\
2405\end{array}$ & $\begin{array}{l}7.12 \\
8.35\end{array}$ \\
\hline Inside the Park (02) & Lisu & 02 & Myanmar & 43 & 280 & 6.51 \\
\hline Total & 06 & 27 & & 1464 & 9618 & Av. 6.22 \\
\hline
\end{tabular}

Table 2. Total number of groups and individuals with age-sex composition recorded from twelve surveyed areas in Namdapha National Park

\begin{tabular}{|c|c|c|c|c|c|c|c|c|c|c|c|c|}
\hline & \multirow[t]{2}{*}{ Locations } & \multirow[t]{2}{*}{ Type of vegetation } & \multicolumn{2}{|c|}{ Adults } & \multicolumn{3}{|c|}{ Immature } & \multirow[t]{2}{*}{$\begin{array}{l}\text { Total } \\
\text { individuals }\end{array}$} & \multicolumn{2}{|c|}{$\begin{array}{l}\text { Mode of sighting } \\
\text { of groups }\end{array}$} & \multirow[t]{2}{*}{$\begin{array}{l}\text { Total } \\
\text { group }\end{array}$} & \multirow[t]{2}{*}{$\begin{array}{l}\text { Average } \\
\text { group size }\end{array}$} \\
\hline & & & $\mathbf{M}$ & $\mathbf{F}$ & SAD & JUV & INF & & $\begin{array}{l}\text { Direct } \\
\text { (Visual) }\end{array}$ & $\begin{array}{l}\text { Indirect } \\
\text { (Song) }\end{array}$ & & \\
\hline 1. & Gibbon land & Tropical evergreen forest & 03 & 03 & - & - & 02 & 08 & 01 & 02 & 03 & 2.66 \\
\hline 2. & Baghnallah & Tropical evergreen forest & 01 & 01 & 01 & - & - & 03 & 01 & - & 01 & 3.00 \\
\hline 3. & Deban & Sub-tropical moist-deciduous & 01 & 01 & - & - & 01 & 03 & 01 & - & 01 & 3.00 \\
\hline 4. & Fifteenth mile & Tropical evergreen forest & 01 & 01 & - & 01 & 01 & 04 & 01 & - & 01 & 4.00 \\
\hline 5. & Sixteenth mile & Tropical evergreen forest & 01 & 01 & - & - & 01 & 03 & 01 & - & 01 & 3.00 \\
\hline 6. & Hawaghar & Tropical evergreen forest & 03 & 03 & - & - & 01 & 07 & - & 03 & 03 & 2.33 \\
\hline 7. & Nineteenth mile & Bamboo thickets & 01 & 01 & - & - & - & 02 & 01 & - & 01 & 2.00 \\
\hline 8. & Haldibari & Tropical evergreen forest & - & - & 01 & - & - & 01 & 01 & - & 01 & 1.00 \\
\hline 9. & Hornbill camp & Tropical evergreen forest & 03 & 03 & - & 01 & 01 & 08 & - & 03 & 03 & 2.66 \\
\hline 10. & Baranallah & Tropical evergreen forest & 01 & 01 & - & - & - & 02 & - & 01 & 01 & 2.00 \\
\hline 11. & Firmbase camp & Tropical evergreen forest & 03 & 03 & - & - & 01 & 07 & 02 & 01 & 03 & 2.33 \\
\hline \multirow[t]{2}{*}{12.} & Embyong & Sub-tropical moist-deciduous & 01 & 01 & - & - & - & 02 & - & 01 & 01 & 2.00 \\
\hline & Total & & 19 & 19 & 02 & 02 & 08 & 50 & 09 & 11 & 20 & 2.50 \\
\hline
\end{tabular}

M - Male; F - Female; SAD - Sub-adult; JUV - Juvenile; INF - Infants

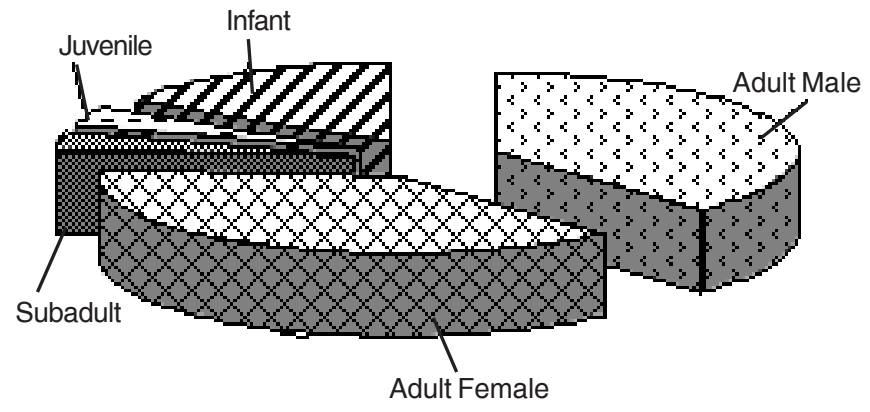

Figure 1. Group composition of Hoolock Gibbon in NNP

to be at 2.5 individuals, ranging from 1 to 4 individuals. The estimated adult sex ratio was $1: 1$.

Temporal sighting period of Hoolock Gibbon in Namdapha National Park

Gibbon sightings at NNP were recorded from 0600hr until the end of sunset. The highest number of groups (30\%) were sighted just after sunrise between $0600 \mathrm{hr}$ and $0700 \mathrm{hr}$ followed by the second highest number of groups (20\%) between $0700 \mathrm{hr}$ and 0800hr (Fig. 2). No gibbon sightings were recorded between 100ohr and $1400 \mathrm{hr}$.

\section{Anthropogenic disturbance and conservation:}

Table 3 expresses the presence of anthropogenic pressure on NNP. While evidence of hunting and poaching was recorded

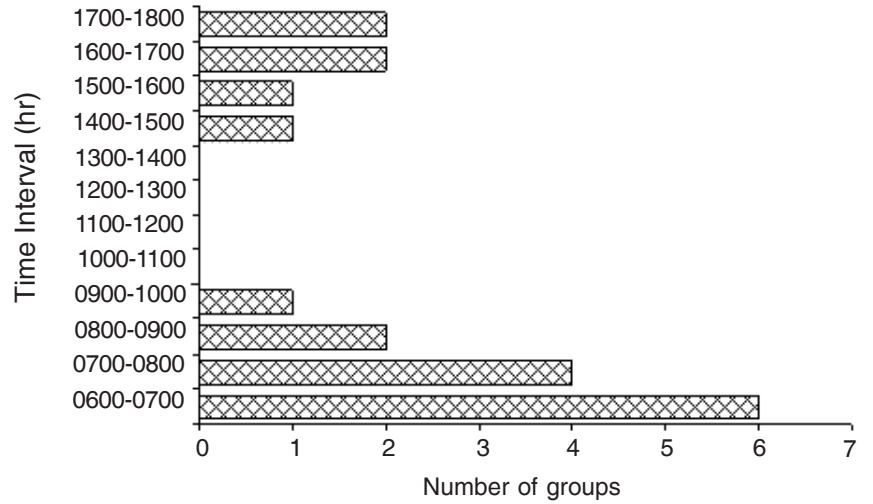

Figure 2. Temporal sighting periods of Hoolock hoolock at Namdapha National Park

in all 12 surveyed areas, timber logging and agricultural activities were absent from the surveyed areas. Hunting, illegal fishing, and trapping of wild fauna like Tiger, Barking Deer, Leaf Deer, Sambar, bear, wild cat, and a variety of birds by local inhabitants, particularly the Lisu, Chakma and Mishmi tribes for bushmeat and their body parts, was a very common phenomenon. Livestock grazing and human settlement were recorded only in the Deban area and in the periphery of the park. Collection of non-timber forest produce (fuelwood, medicinal plants, wild vegetable and housing materials) and tourism pressure were recorded in the Gibbon Land, Baghnallah, Deban, Fifteenth Mile, Hawaghar, Haldibari, and Hornbill camp sites. All of these 


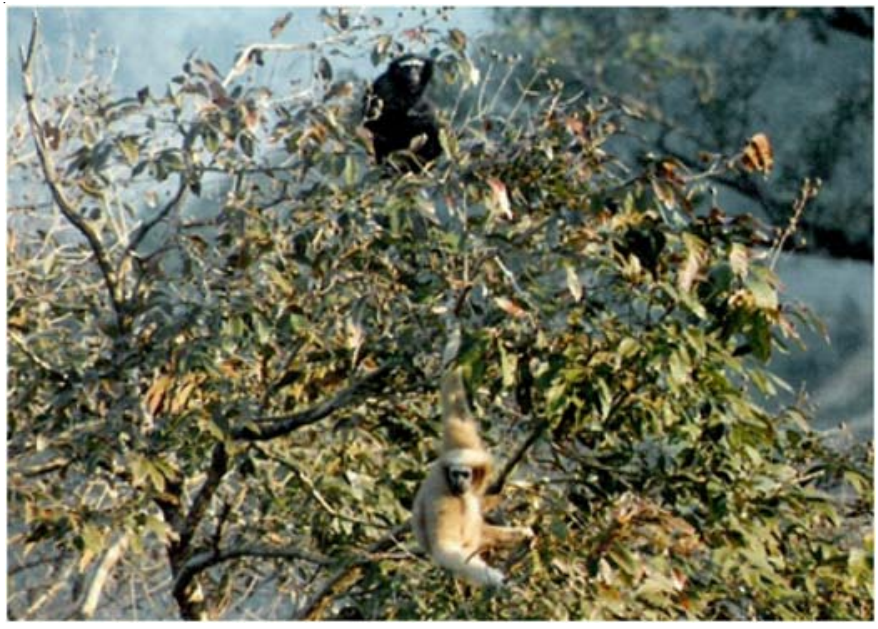

Image 1. A pair of adult male and female gibbons feeding.

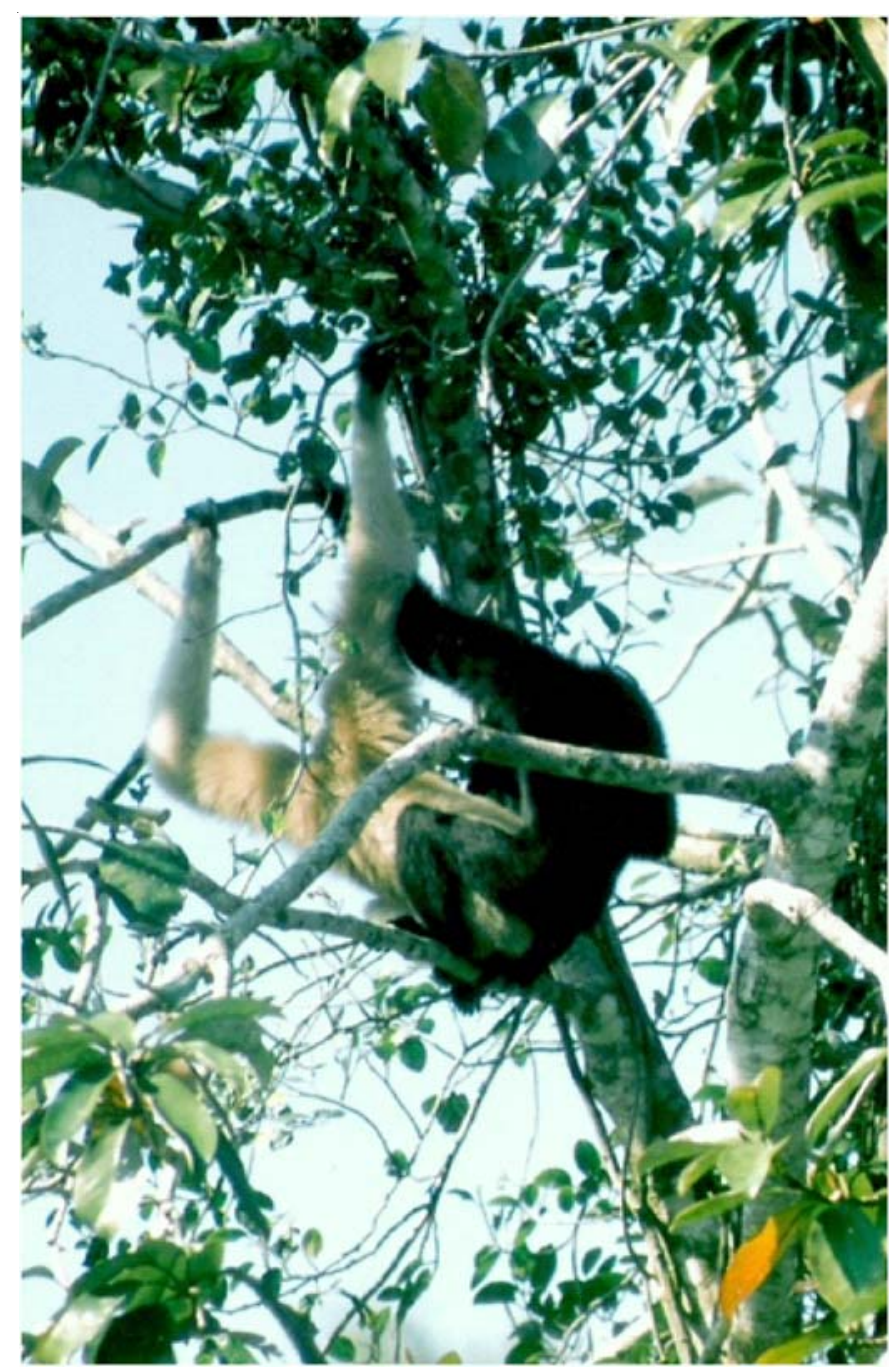

Image 2. Adult male and female gibbons in copulation.

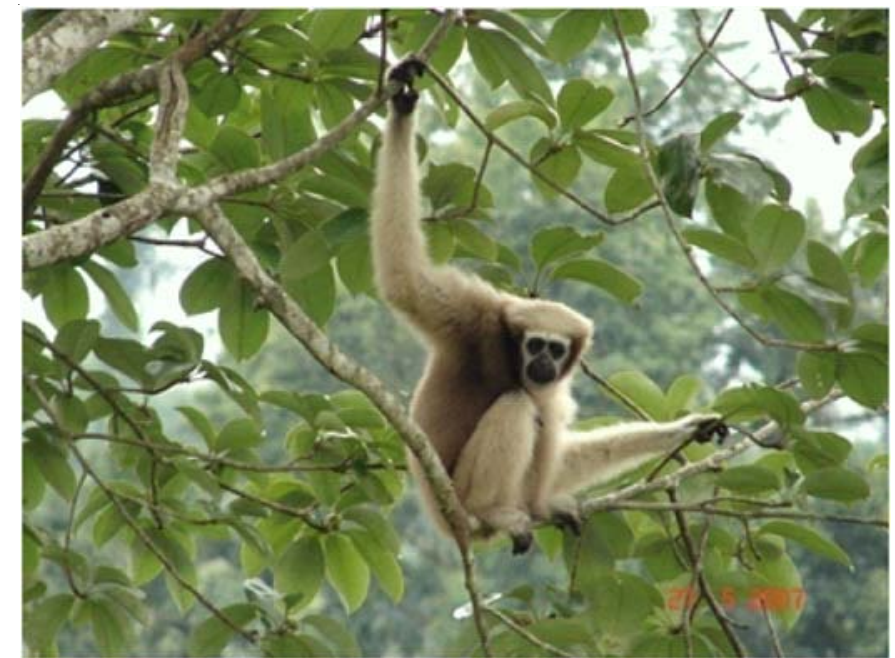

Image 3. Pregnant female gibbon.

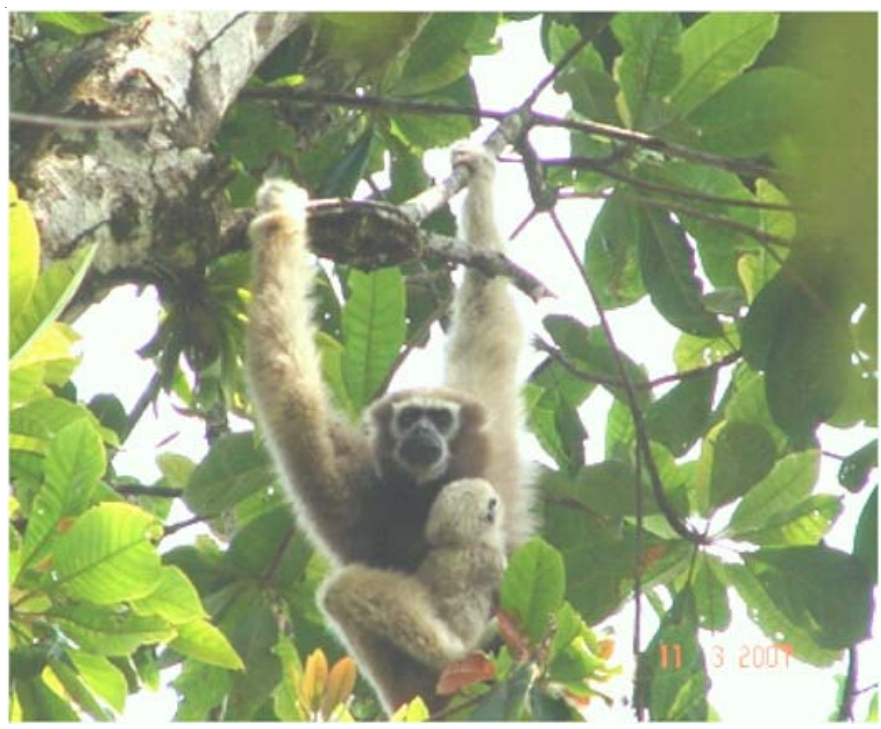

Image 4. Female carrying newly born infant.

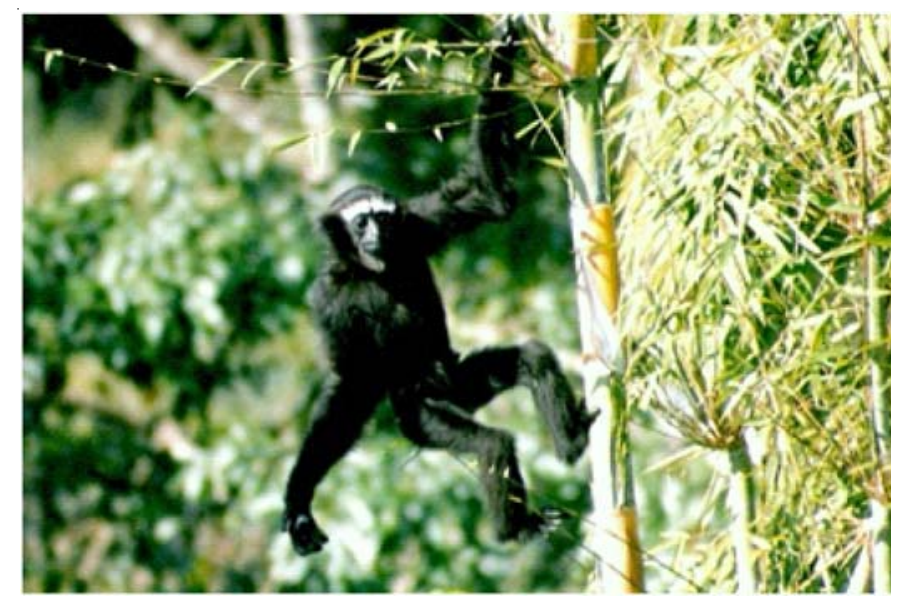

Image 5. Juvenile male in bamboo forest. 
Table 3. Extraction of forest products in select villages in and around Namdapha National Park (from Arunachalam et al. 2004).

\begin{tabular}{|c|c|c|c|c|c|c|c|c|c|}
\hline \multirow[b]{2}{*}{ Name of villages } & \multicolumn{3}{|c|}{ Demography } & \multicolumn{4}{|c|}{ Extraction of forest products(tons village ${ }^{-1} \mathrm{yr}^{-1}$ ) } & \multicolumn{2}{|c|}{$\begin{array}{l}\text { Average seasonal fuelwood } \\
\text { consumption (tons village } \\
\text { season }^{-1} \text { ) }\end{array}$} \\
\hline & Community & $\begin{array}{l}\text { Total } \\
\text { household }\end{array}$ & $\begin{array}{l}\text { Human } \\
\text { population }\end{array}$ & $\begin{array}{l}\text { Bamboos } \\
\text { and posts } \\
\text { (dry wt.) }\end{array}$ & $\begin{array}{l}\text { Roofing } \\
\text { material } \\
\text { (dry wt.) }\end{array}$ & $\begin{array}{l}\text { Fire wood } \\
\text { (dry wt.) }\end{array}$ & $\begin{array}{l}\text { Wild vegetable } \\
\& \text { medicinal } \\
\text { plant(fresh wt.) }\end{array}$ & $\begin{array}{l}\text { Summer } \\
\text { (April-Sept.) }\end{array}$ & $\begin{array}{l}\text { Winter } \\
\text { (Oct.-March) }\end{array}$ \\
\hline Lama basti & Lama & 23 & 122 & 57.5 & 3.0 & 100.2 & 0.2 & 46.05 & 54.72 \\
\hline Budhisatta & Chakma & 56 & 293 & 140.0 & 7.4 & 320.8 & 5.5 & 132.50 & 186.48 \\
\hline Anandapur-I & Chakma & 55 & 315 & 137.5 & 7.3 & 287.4 & 5.6 & 115.02 & 171.11 \\
\hline Anandapur-II & Chakma & 38 & 216 & 95.0 & 5.0 & 236.5 & 7.0 & 96.82 & 139.08 \\
\hline M'pen-I & Chakma & 95 & 585 & 237.5 & 12.5 & 480.4 & 13.0 & 214.40 & 269.38 \\
\hline M'pen-II & Chakma & 78 & 457 & 195.0 & 10.3 & 417.0 & 9.0 & 170.35 & 242.66 \\
\hline $38^{\text {th }}$ mile & Lisu & 25 & 165 & 62.5 & 2.6 & 165.6 & 2.6 & 74.98 & 91.50 \\
\hline $52^{\text {nd }}$ mile & Lisu & 20 & 130 & 50.0 & 3.3 & 142.3 & 2.6 & 58.24 & 84.18 \\
\hline Total & & 390 & 2283 & 975.0 & 51.4 & 2150.2 & 45.5 & 908.36 & 1239.11 \\
\hline
\end{tabular}

Table 4. Comparison of group composition and group size of Hoolock hoolock in Namdapha National Park

\begin{tabular}{|c|c|c|c|c|c|c|c|}
\hline & No. of Groups & Total Population & Adult & Sub adult & Juveniles & Infants & Group Size \\
\hline Present study & 20 & 50 & $76 \%$ & $4 \%$ & $4 \%$ & $16 \%$ & 2.5 \\
\hline Chetry et al. 2003 & 10 & 33 & $61 \%$ & - & $30 . \%$ & $09 . \%$ & 3.3 \\
\hline
\end{tabular}

areas are located inside the buffer zone of NNP.

\section{Discussion}

Hoolock hoolock survive primarily in tropical evergreen forests, tropical wet evergreen forests, tropical semi-evergreen, tropical moist deciduous, and subtropical hill forests in India (Srivastava 1999; Molur et al. 2005). This study clearly shows $75 \%$ of the gibbons we observed in tropical evergreen forest, ranging from 150 to $800 \mathrm{~m}$ in elevation. As this species is largely frugivorous, food availability may be a limiting factor for its distribution versus for a folivorous primate species (Joseph \& Ramachandran 2003). The status of gibbons in the state is not conclusively known. There are only mentions of their presence or absence from protected and non-protected areas. There is hardly any quantitative information on the population estimation of $H$. hoolock based on systematic studies in NNP with the lone exception of Chetry et al. (2003) (Table 4). They reported 10 groups of $H$. hoolock comprising 33 individuals in NNP during the 2002 survey. Choudhury (1990) reported $168 \mathrm{H}$. hoolock in seven populations for the state. In comparison, in other northeastern states Das et al. (2005) reported the occurrence of H. hoolock populations in Assam (1994) and Tripura (2003) comprising 1985 and 97 individuals, respectively. H. hoolock are monogamous, maintain a social network within a group and social proximity with neighboring groups of the same species (Alfred \& Sati 1990). Alfred \& Sati (1990) also reported that a typical family group consists of a mated pair and one to three immature offspring. We compared our group composition and group size with Chetry et al. (2003) for NNP and these data are presented in Table 4. Our group size of 2.5 individuals for 20 groups is closely comparable to other studies conducted in different part of $H$. hoolock distribution range: 3.2 individuals for 24 groups and 3.4 for seven groups (Tilson 1979), 3.1 for eight groups and 3.0 for 14 groups (Chaudhury 1990, 1991) in Assam, 3-3.2 for six to 10 groups (Mukherjee 1982), 2.1 for 34 groups (Gupta 1994) in Tripura, 3.0 individual for 42 groups (Alfred \& Sati 1990) in Meghalaya, 3.5 for six groups (Gittins
1984), 2.3 for five groups and 2.9 for 15 groups (Ahsan 1984, 1994), and 2.9 for 13 groups (Feeroz \& Islam 1992) in Bangladesh.

The economic status of local people affects the gibbon population and its habitat directly and indirectly and this has become a major concern for gibbon conservation. Arunachalam et al. (2004) explained the present inherent dependency of the local people on forest resources, particularly those settled in peripheral areas and inside NNP (Table.3). Local people use forest resources and land for extracting fuelwood, housing materials, medicinal plants, wild vegetables, and for agricultural activities. This results in forest fragmentation and degradation in the form of canopy gaps, and food paucity in both quantity and quality. In northeastern India, Bangladesh and Myanmar, most H. hoolock habitat is fragmented (Molur et al 2005; Walker et al. 2007). This makes gibbons particularly vulnerable to hunting and predation by domestic and wild dogs while moving on forest floor to forage for food, mate, and find safe shelter (C. Loma, Conservator of Forests, Arunachal Pradesh Forest Department, pers. comm.). Community hunting for their flesh and socio-cultural practices by tribal people is one of the major threats to primate species, including the endangered $H$. hoolock (Biswas 1970; Solanki \& Chutia 2004). Further, the songs of gibbons act as a definite guide for hunters, allowing them to locate gibbons easily (Gupta et al. 2005). This has resulted in a sharp decline of gibbon populations in the entire northeast. The majority of gibbon populations in the northeast are very small and declining (Choudhury 1996b; Mukherjee et al. 19911992; Molur et al. 2005; Walker et al. 2007) and several fragmented populations face a high probability of extinction $(75 \%)$ in the near future (Molur et al. 2005) due to isolation, decrease in habitat quality, availability of food and hunting. Gupta et al. (2005) stated that the alarming changes in gibbon habitat that has taken place in the recent years, in the ecology and landscape, have brought about a number of changes in the distribution and population structure of H. hoolock in the species' range. $H$. hoolock can be considered a keystone and flagship species, as it helps in the local health of the forest, is a state 
animal and is a tourist attraction.

\section{Recommendations}

The interdependence of primates and the local people on one common resource for their basic requirements is the main cause for concern. Success in conservation goals would largely depend on the effectiveness with which this interdependence is lessened.

1. The present study recommends that human activities should be controlled in NNP in order to conserve H. hoolock populations.

2. The population should be monitored at regular intervals to evaluate the success of the management and conservation actions that have been implemented.

3. Alternative means of survival of local people should be sought by the state government particularly by the park authority in order to provide a lasting solution to the population.

4. The State Forest Department should launch well developed and planned agro-forestry and social forestry program specifically designed as per the requirements of the local people inhabiting in and around the park.

5. Fragmented, degraded forests and canopy gaps that exist in the gibbon's habitats in Namdapha National Park should be restored by planting of preferred and fast growing food plants.

6. The population, which requires immediate protection and conservation due to canopy gaps and lack of food availability, should be located and provided some alternative means for the movement of gibbons from one fragmented patch to another like bamboo bridges or rope way bridges which have been successfully experimented with in the Gibbon Wildlife Sanctuary, Assam to reduce canopy gaps.

7. A community education program for local people and a visitor center should be established. Salient features of gibbons, such as behavior, ecology, and socio-biology, as well as the importance of the species to humans, should be highlighted using banners, posters, and leaflets. These should freely distributed to create awareness of the species.

8. In line with tiger, lion, elephant and crocodile projects, the government should also start a Hoolock Gibbon project for the entire range of the species to determine the present distribution, population status, evaluate threats and conserve the species.

\section{References}

Ahmed, A. (2001). Illegal trade, and utilization of primates in India. In: Gupta, A.K. (ed.) Non-human Primates of India, ENVIS Bulletin: Wildlife and Protected Area 1(1): 177-184.

Ahsan, M.F. (1994). Ecology of the Hoolock Gibbon (Hylobates hoolock) in Bangladesh. Ph.D. Dissertation, University of Cambridge, Cambridge, UK

Ahsan, M.F. (1984). Study on primates in Bangladesh: Determination of population status and distribution of non-human primates in Bangladesh with emphasis on Rhesus Monkey. M.Phil. Thesis, University of Dhaka, Bangladesh.

Alfred J.R.B. \& J.P. Sati (1986). The gibbon with special reference to Hylobates Hoolock, pp. 384-390. In: Majupuria, T.C. (ed.) Wildlife Wealth of India Resources and Management. Tec. Press Service, Bangkok.

Alfred, J.R.B. \& J.P. Sati (1990). Survey and census of the Hoolock Gibbon in West Garo Hills, northeast India. Primates 31(2): 299-306.

Anderson, J. (1878). Anatomical and zoological researches. Comprising the account of zoological results in two expeditions to western Yunnan in 1868 and 1875. Quaritch, London

Arunachalam, A., R. Sarmah, D. Adhikari, M. Majumdar \& M.L. Khan
(2004). Anthropogenic threats and biodiversity conservation in Namdapha nature reserve in the Indian Eastern Himalaya. Current Science 87(4): $447-454$.

Biswas, S. (1970). White-browed Gibbon (Hylobates hoolock Harlan) and Capped Langur (Presbytis pileatus Blyth) as human food. Journal of Bombay Natural History Society 36(1): 78-80.

Borang, A. \& G.S. Thapliyal (1993). Natural Distribution and ecological status of non human primates in Arunachal Pradesh. Indian Forester $119(10): 834-844$.

Brandon-Jones, D., A.A. Eudey, T. Geissmann, C.P. Groves, D.J. Melnick, J.C. Morales, M. Shekelle \& C.B. Stewart (2004). Asian primate classification. International Journal of Primatology 25: 97164 .

Brockelman, W., S. Molur \& T. Geissmann (2008). Hoolock hoolock. In: IUCN 2008. 2008 IUCN Red List of Threatened Species. <www.iucnredlist.org >. Downloaded on 10 April 2009.

Burnham, K.P., D.R. Anderson \& J.L. Laake (1980). Estimate of Density from Line Transect Sampling of Biological Populations. Wildlife Monograph 72. The Wildlife Society, Washington D.C.

Champion, H.G. \& S.K. Seth (1968). A Revised Survey of Forest Types of India, Govt. of India, New Delhi.

Chetry, D, R. Medhi, J. Biswas, D. Das \& P.C. Bhattacharjee (2003). Nonhuman Primates in the Namdapha National Park, Arunachal Pradesh, India. International Journal of Primatology 24(2): 383-388.

Choudhury, A.U. (1987). Notes on the distribution and conservation of Phayre's Leaf Monkey and Hoolock Gibbon in India. Tiger Paper 14(2): 2-6.

Choudhury, A.U. (1990). Population dynamics of Hoolock Gibbons (Hylobates hoolock) in Assam, India. American Journal of Primatology 20: 37-41.

Choudhury, A.U. (1991). Ecology of the Hoolock Gibbon (Hylobates hoolock) a lesser ape in the tropical forests of northeastern India. Journal of Tropical Ecology 7: 147-153.

Choudhury, A.U. (1998). A survey of primates in the Jaintia Hills. ASP Bulletin 22(3): 8-9.

Choudhury, A.U. (2000). A survey of Hoolock Gibbon (Hylobates hoolock) in Dibru-Saikhowa National Park, Assam, India. Primate Report 56: $61-66$.

Choudhury, A.U. (2001). Primates in northeast India: An overview of their distribution and conservation. ENVIS Bulletin: Wildlife and Protected Areas 1(1): 92-101.

Choudhury, A.U. (2003). The Mammals of Arunachal Pradesh. Regency Publications, New Delhi.

Choudhury, A.U. (1996a). A survey of Hoolock Gibbon (Hylobates hoolock) in southern Assam, India. Primate Report 44: 77-85

Choudhury, A.U. (1996b). Primates in Bherjan, Borajan, and Podumani Reserve Forests of Assam, India, Asian Primates 5 (3-4): 10-11.

Das, J., M.M. Feeroz, M.A. Islam, J. Biswas, P. Bujarborua, D. Chetry, R. Medhi \& J. Bose (2003a). Distribution of Hoolock Gibbon (Bunopithecus hoolock hoolock) in India and Bangladesh. Zoos' Print Journal 18(1): 969-976.

Das, J., J. Biswas, R. Medhi, J. Bose, D. Chetry, P. Bujorborua \& F. Begum (2003b). Distributional status of Hoolock Gibbon (Bunopithecus hoolock) and their conservation in southern Assam, India. Tiger paper 30(4): 26-29.

Das, J., P.C. Bhattacharjee, J. Biswas \& D. Chetry (2004). Western Hoolock Gibbon: Socioecology, Threats and Conservation Action Plan. A report of Primate Research Center, Guwahati University, Assam.

Das, J., P.C. Bhattacherjee, J. Biswas \& D. Chetry (2005). Western Hoolock Gibbon: Socioecology, Threats and Conservation Action Plan. Department of Zoology, Guwahati University, and Primate Research Centre, Northeast Centre, Guwahati, India. 70pp.

Das, J., J. Biswas, P.C. Bhattacharjee \& S.M. Mohnot (2006). First distribution records of the Eastern Hoolock Gibbon (Hoolock hoolock leuconedys) from India. Zoos' Print Journal 21(7): 2316-2320.

Feeroz M.M. \& M.A. Islam (1992). Ecology and behavior of Hoolock Gibbon of Bangladesh. MARC (Multidisciplinary Action Research Centre), Dhaka, Bangladesh.

Ghosh, A.K. (1987). Quantitative analysis of faunal resources of proposed Namdapha Biosphere Reserve. Zoological Survey of India.

Gittins, S.P. (1984). The distribution and status of gibbons in Bangladesh. In: The Lesser Apes: Evolutionary and Behavioural Biology $(\mathrm{H}$. 
Preuschaft, D. Chivers, N. Creel and W. Brockelman eds.) Edinburgh University Press,. Edinburgh: 13-15.

Groves, C.P. (2005). Order Primates, pp.111-184. In: Wilson, D.E. \& D.M Reeder. Mammal Species of the World: A Taxonomic and Geographic Reference, $3^{\text {rd }}$ Edition, Volume 1. Johns Hopkins University Press, Baltimore.

Groves, C.P. (1967). Geographic variation in the Hoolock Gibbon or Whitebrowed Gibbon (Hylobates hoolock Harlan). Folia Primatologica 7: 276-283.

Groves, C.P. (1971). Geographic and individuals variation in Bornean gibbons, with remarks on systematics of subgenus Hylobates. Folia Primatologica 14: 139-153.

Groves, C.P. (1972). Systematic and Phylogeny of gibbons. In: Rumbhaugh, D.M. (ed). Gibbon and Siamang Vol. 1. Karger, Basel. pp. 1-89,

Gupta, A.K. (1994). Status and conservation of non-human primates in Tripura, India. Pp 101-111. In: Thierry, B., J.R., Anderson, J.R., Roeder, J.J., \& N. Herrenschmidt (eds.) Current Primatology, Strasbourg, France, Universite Louis-Pasterur.

Gupta, A.K. \& S. Dasgupta (2005). Conservation status of Hoolock Gibbon (Bunopithecus hoolock) in Tripura. ENVIS Bulletin:Wildlife and Protected Areas 8: 151-170.

Gupta, A.K. \& N. Sharma (2005a). Conservation status of Hoolock gibbon (Binopithecus Hoolock) in Meghalaya. In: Gupta, A.K., N. Sharma, S. Dasgupta, D. Chakraborty \& R. Hazarika (eds.) Conservation of Hoolock Gibbon in Northeast India. ENVIS Bulletin:Wildlife and Protected Areas 8 : 87-150.

Gupta, A.K. \& N. Sharma (2005b). Conservation status of Hoolock gibbon (Binopithecus Hoolock) in Mizoram. In: Gupta, A.K., N. Sharma, S. Dasgupta, D. Chakraborty, D. \& R. Hazarika (eds.) Conservation of Hoolock Gibbon in Northeast India. ENVIS Bulletin: Wildlife and Protected Areas 8: 27-86.

Gupta, A.K., N. Sharma, S. Dasgupta, D. Chakraborty \& R. Hazarika (2005). Conservation of Hoolock Gibbon (Bunopithecus hoolock) in northeast India. ENVIS: Wildlife and Protected Areas 8: 1-26

Hajra, P.K. (1996). A contribution to the Flora of Namdapha, Arunachal Pradesh, Botanical Survey of India, Calcutta, India. 257pp.

Harlan, R. (1831). Description of a new species of orang (Simia hoolock) from the north-eastern province of British East India, lately the kingdom of Assam. Transactions of the American Philosophical Society 4.(1): 52-59.

Howe, H.F. (1986). Seed dispersal by fruit-eating birds and mammals, pp. 123189. In: Murray, D.R. (ed.) Seed Dispersal. Academic Press, Sydney.

Joseph, G.K. \& K.K. Ramachandran (2003). Distribution and demography of the Nilgiri Langur (Trachypithecus johnii) in Silent Valley National Park and adjacent areas, Kerala, India. Primate Conservation 19: 78-82.

Kumar, A. \& G.S. Solanki (2004). Ethno-sociological Impact on Capped Langur (Trachypithecus pileatus), and suggestions for conservation: A Case Study of Reserve Forest in Assam, India. Journal of Nature Conservation 16(1): 107-113.

Kumar, R.S., C. Mishra \& A. Sinha (2005). Discovery of the Tibetan Macaque Macaca thibetana in Arunachal Pradesh, India, Current Science 88(9): 10

Lan, D. (1994). Progress of the surveys of Hoolock Gibbon in Yunan: Distribution, Population size, Habitat and conservation. Chinese Primate Research and Conservation Neres 3(1): 8-10

Malone, N., A.R. Purnama, M. Wedana \& A. Fuentes (2002). Assessment of the sale of primate at Indonesian bird markets. Asian Primate 8(1-2): 711

McCann, C. (1933). Notes on the colouration and habits of the White-browed Gibbon or Hoolock (Hylobates hoolock Harl.). Journal of Bombay Natural History Society 36: 395-405.

Misra, C., T. Raman \& A. Johnsingh (1994). Survey of primates, serow, and goral in Mizoram. Report, Wildlife Institute of India, Dehra Dun.

Molur, S., D. Brandon-Jones, W. Dittus, A. Eudey, A. Kumar, M. Singh, M.M. Feeroz, M. Chalise, P. Priya \& S. Walker (eds.) (2003). Status of South Asian Primates: Conservation Assessment and Management Plan (C.A.M.P.) Workshop Report, 2003. Zoo Outreach Organisation.CBSG-South Asia, Coimbatore, India, viii+432pp

Molur, S., S. Walker, A. Islam, P. Miller, C. Srinivasulu, P.O. Nameer, B.A. Daniel \& L. Ravikumar (eds.) (2005). Conservation of Western Hoolock Gibbon (Hoolock hoolock hoolock) in India and Bangladesh. Zoo Outreach organisation/ CBSG-South Asia, Coimbatore, 132pp.

Mootnick, A. \& C.P. Groves (2005). A new generic name for the Hoolock Gibbon (Hylobatidae). International Journal of Primatology 26(4): 972976.

Mukherjee, R.P. (1982). Survey of non-human primates of Tripura. India. Journal of Zoological Society of India 34(1-20): 70-81.
Mukherjee, R.P., S. Chaudhury \& A. Murmu (1988). Hoolock Gibbons in Arunachal Pradesh, Northeast India. Primates Conservation 9:12 1-123.

Mukherjee, R.P., S. Choudhury \& A. Murmu (1991-92). Hoolock gibbon in Arunachal Pradesh, Northeast India: Lohit district. Primate Conservation 12-13: 31-33.

Nath, P.C., A. Arunachalam, M.L. Khan, K. Arunachalam \& A.R. Barbhuiya (2005). Vegetation analysis and tree population structure of tropical wet evergreen forests in and around Namdapha National Park, Northeast India. Biodiversity Conservation 14: 2 109-2 136.

NRC (1981). Techniques for the study of primate population Ecology. (National Research Council, National Academy Press, Washington, D.C. $227 \mathrm{pp}$.

Parsons, R.E. (1941). Rivers as barriers to the distribution of gibbons. Journal of the Bombay Natural History Society 42: 434 \& 926

Prouty, L.A., P.D. Buchanan, W.S. Pollitzer \& A.R. Mootnick (1983a). A presumptive new hylobatid subgenus with 38 chromosomes. Cytogenet. Cell Genetics 35: 141-142.

Prouty, L.A., P.D. Buchanan, W.S. Pollitzer \& A.R. Mootnick (1983b). Bunopithecus: A genus-level taxon for the Hoolock Gibbon (Hylobates hoolock). American Journal of Primatology 5: 83-87.

Siddiqui, N.A. (1986). Gibbon in the West Banugach Reserved Forests of Sylhet district, Bangladesh. Tiger Paper 8(3): 29-31.

Singh, D.N. (2001). Status and distribution of primates in Arunachal Pradesh In: Gupta, A.K. (ed.) Non-human Primates of India. ENVIS Bulletin:Wildlife and Protected Area 1(1): 113-1 19

Sinha, A., A. Datta, M.D. Madhusudan \& C. Mishra (2005). Macaca munzala: A new species from western Arunachal Pradesh, northeastern India International Journal of Primatology 26(4): 977-989.

Solanki, G.S. \& P. Chutia (2004). Ethno Zoological and Socio-cultural aspects of Monpas of Arunachal Pradesh. Journal of Human Ecology 15(4): 251-254.

Srivastava, A. (1999). Primates of Northeast India. Megadiversity Press, Bikaner,207pp.

Srivastava, A. \& M.S. Mohnot (2001). Distribution, conservation status and priorities for primates in Northeast India. ENVIS Bulletin: Wildlife and Protected Areas 1(1): 102-108.

Srivastava, A., D. Chetry, P. Bujarbarua, J. Das \& P. Sarkar (2001a). Status of primates in the Gibbon Wildlife Sanctuary, Assam, India. Biosphere Conservation 4.(1): 43-49.

Srivastava, A., J. Das, J. Biswas, P. Bujarbarua, P. Sarkar, I.S. Bernstein \& S.M. Mohnot (2001b). Primate population decline in response to habitat loss: Borajan Reserve Forest of Assam, India. Primates 42(4): 401-406.

Terborgh, J. (1990). Seed and fruit dispersal-commentary, pp.181-190. In: Bawa, K.S. \& M. Handley (eds). Reproductive ecology of tropical forest plants. The Parthenon Publishing Group, Paris.

Tickell, S.R. (1864). Notes on the gibbon on Tenasserim, Hylobytes lar. Journal of Asiatic Society of Bengal 33: 196-199.

Tilson, R.L. (1979). Behaviour of Hoolock Gibbon (Hylobates hoolock) during different seasons in Assam, India. Journal of the Bombay Natural History Society 76(1): 1-16

Walker, S., S. Molur \& W.Y. Brockelman (2007). Western Hoolock Gibbon, Hoolock hoolock (Harlan, 1831), pp. 18. In: Primates in Peril: The World's 25 Most Endangered Primates 2006-2008, Mittermeier, R.A., J. Ratsimbazafy, A.B. Rylands, L. Williamson, J.F. Oates, D. Mbora, J.U. Ganzhorn, E. Rodríguez-Luna, E. Palacios, E.W. Heymann, M.C.M. Kierulff, L. Yongcheng, J. Supriatna, C. Roos, S. Walker \& J.M. Aguiar. Primate Conservation 22: 1-40.

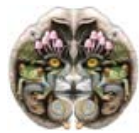


Author Details: Dr. AwadHesh KUmAR is an animal behavioral ecologist and wildlife conservationist. He has obtained his Masters degree in Forestry, Wildlife \& Environmental Science from G. G. University, Bilaspur, and completed his doctorate degree from North-Eastern Hill University Shillong in Zoology (Wildlife Behavioural Ecology). He joined as faculty of Department of Forestry at NERIST in June 2006 and is engaged in teaching wildlife ecology, management, and conservation to undergraduate and post-graduate students of forestry.

Dr. (Mrs.) P. P. MARY is an animal biologist. She completed her doctorate from the Centre of Advanced Study in Marine Biology, Annamalai University (Tamil Nadu). She joined as faculty of Forestry at NERIST in February 1986 and is engaged in teaching wildlife resources utilization and conservation to undergraduate and post-graduate students of forestry.

Mr. Pushral Bagchie is a student of B.Sc. Forestry and has completed his graduate degree from NERIST in Forestry and is presently pursuing a post graduate degree in forestry from ICFRI, Dehra Dun.

Acknowledgement: We would like to thank Mr. M.K. Palit, Deputy Conservator of Forest (Wildlife), Department of Forests, Govt. of Arunachal Pradesh for providing us with the permission to carry out this work in Namdapha National Park. We also thank the Field Director, Namdapha NP and Dr. Chandiramani, Research Officer and his field staff for the necessary logistic and manpower support for the successful completion of the work. We offer our sincere thanks to the Director, NERIST and Dr. P. Rethy, Head, Department of Forestry for providing the necessary facilities and help during the study. We are particularly grateful to Mr. C. Loma, Deputy Chief Wildlife Warden for providing photographs and information on gibbon, Mr. Tai Dora for his physical help during field work, Dr. Dibyendu Adhikari and Dr. Atiqur Rahman, for sharing much of their vital information regarding Namdapha National Park. We finally thank all the reviewers for critically evaluating, editing and giving constructive suggestions for improving the standard of the manuscript and $\mathrm{Mr}$. Raju Barthakur, Lecturer in English, Department of Humanities and Social Sciences, NERIST for Linguistic suggestions and editing. 